\title{
PEMERINTAHAN ALLAH DAN MASYARAKAT EKONOMI ASEAN: REFLEKSI INJILI
}

\author{
Mulyo Kadarmanto
}

\begin{abstract}
Abstrak: Tulisan ini bertujuan untuk membahas pemerintahan Allah meyakini dan otoritas umat-Nya dalam menjawab tantangan kekinian, khususnya dalam menghadapi Masyarakat Ekonomi ASEAN. Pemerintahan Allah dan otoritas umat-Nya seringkali dipahami oleh gereja injili sebagai pemerintahan dan otoritas rohani semata, sehingga mengalami hambatan dan ketidakmampuan merelevansikan ajaran tersebut dalam tantangan kekinian. Oleh karena itulah, tulisan ini kembali melihat Allah sebagai pribadi yang berdaulat dan menyatakan pemerintahan-Nya yang menempatkan orang percaya berada dalam bagian pemerintahan-Nya untuk terlibat aktif dalam tanggung jawab di dunia sebagai representasi Allah, dan khususnya dalam konteks globalisasi ini, umat Allah menerima otoritas sebagai "globalizer".
\end{abstract}

Kata Kunci: Otoritas, pemerintahan, umat Allah, globalizer, MEA.

\section{PENDAHULUAN}

Allah telah mengaruniakan otoritas atas warga kerajaan-Nya, otoritas anak-anak Allah yang merupakan bagian dari pemerintahan Allah, namun seringkali hanya dipahami sebagai otoritas yang bersifat spiritual dan futuristik. Otoritas spiritual yang ditenggarai sebagai kuasa untuk mengalahkan kejahatan, yang disebabkan cara pandang memahami peperangan anak-anak Allah bukanlah melawan darah dan daging, tetapi melawan penguasapenguasa jahat; sehingga yang dibutuhkan dalam menjalani kehidupan di tengah dunia yang jahat ini adalah otoritas yang tertuju hanya kepada hal-hal spiritual. Dengan begitu terobsesinya pada kemenangan spiritual tersebut, sehingga mengaburkan nilai-nilai bahwa pemerintahan Allah dimana umat menjadi bagian didalamnya juga memiliki mandat budaya.

Selain itu, Allah dalam atribut-Nya seringkali hanya "diperalat" untuk memuaskan keinginan dan menenteramkan hati umat sebagai sumber segala 
berkat yang menjadi jaminan akan kesuksesan, sedangkan berbicara tanggung jawab umat seringkali dalam bentuk spiritual semata, namun bukan sesuatu yang nyata dalam tindakan dan langsung berkaitan dengan permasalahan kekinian. Dari hal-hal tersebut nyatalah akan kesejajaran pemahaman bahwa Allah dan atribut-Nya, kerajaan dan pemerintahan-Nya, serta otoritas yang diberikan kepada umat-Nya ada dalam wilayah spiritual (rohani), sehingga berakibat pengikisan kepada cara pandang akan kekinian dengan seluruh permasalahannya.

Untuk itulah dalam bagian penulisan ini mencoba untuk melihat Allah dan pemerintahan-Nya yang telah mengaruniakan otoritas tersebut, diawali dengan melihat kecenderungan pada masa kini dalam memahami Allah dan otoritas yang diberikan-Nya, yang kemudian dilanjutkan dengan melihat pemerintahan Allah dan otoritas umat-Nya, dan pada akhirnya akan menjawab pergumulan terkini, khususnya peran umat Allah menyongsong Masyarakat Ekonomi ASEAN (selanjutnya: MEA), yang merupakan perwujudan visi masyarakat ASEAN sebagai satu komunitas yang akan sudah direalisasikan dipenghujung tahun 2015.

\section{TREN INJILI MEMAHAMI ALLAH DAN PEMERINTAHAN-NYA}

\section{Atribut dan Karya Allah Sebagai Dasar Kesuksesan}

Jika diamati pada masa kini, mungkin teologi kemakmuran bukanlah sesuatu yang menarik lagi khususnya dikalangan gereja injili kharismatik. Kendati masih banyak juga yang tetap menyajikan mimbar gereja dengan "mempromosikan" Allah sebagai Raja yang berdaulat dan berkuasa untuk memberikan segala kelimpahan dan kemakmuran tanpa berbagai kesulitan untuk anak-anak-Nya. Namun bukan berarti ajaran tersebut sudah usang dan menghilang, mengingat masih begitu banyak gereja dan para pengkhotbah yang terus berinovasi untuk terus mengemas dan melanjutkan tradisi ajaran ini. Dengan pengajaran yang menekankan bahwa Allah sebagai pribadi yang Mahabesar, kaya dan penuh berkat. Dengan mengambil atribut-atribut Allah tersebut, kemudian mengaplikasikannya dengan menyatakan bahwa setiap orang percaya yang menjadi anak Allah (Raja), pastilah kehidupan akan 
berjalan dengan tidak merasakan masa-masa sulit, penderitaan dan sakit penyakit.

Di sisi lain, ke-Mahabesaran Allah tersebut, dilihat sebagai satu kesempatan menarik kelimpahan sebanyak-banyaknya, sehingga segala sesuatu yang diberikan orang percaya kepada Allah adalah investasi. ${ }^{1}$ Allah sebagai Pribadi yang mengelola investasi orang percaya. Dengan atribut-Nya sebagai pribadi yang Mahabesar ditambah dengan "penanaman modal" orang percaya, maka diyakini bahwa sudah pasti Allah akan memberkati kelimpahan atas kehidupan orang percaya dan tidak akan pernah mengalami masa-masa sulit.

Kini, ajaran tersebut telah memiliki satu kemasan baru, yang memperlihatkan bahwa Allah telah menentukan umat-Nya sebagai orang-orang yang memiliki otoritas untuk berkuasa atas kehidupan. Allah sebagai pribadi yang penuh anugerah telah melimpahkan anugerah-Nya, yang telah dikerjakan didalam diri Yesus Kristus. Karena Yesus telah "selesai" mengerjakan karya-Nya di atas kayu salib, maka Ia adalah Tuhan dan karena itu ia menempatkan orang percaya untuk memerintah dan berkuasa atas seluruh aspek kehidupan. Aspek-aspek yang dimaksudkan dalam bagian ini merupakan aspek kehidupan yang berada dalam lingkup dosa, kegelapan, kejahatan, kemiskinan, kutukan, dan penyakit.

Joseph Prince dalam bukunya yang berjudul Destined to Reign, menyatakan bahwa Allah sesungguhnya telah mengaruniakan otoritas-Nya bagi anak-anak kerajaan-Nya untuk berkuasa dan memerintah atas kehidupan di dunia ini. Istilah "memerintah atau menguasai" yang dimaksudkan oleh Joseph Prince didasarkan atas Roma 5:17, yang diartikan sebagai "kingly, judicial rule". Dengan kata lain, ini menunjukan bahwa orang percaya akan menguasai atau memerintah dalam hidup sebagai seorang raja, karena telah menerima pembebasan secara sempurna, inilah kemasan baru yang saat ini dikenal sebagai hyper-grace dalam kalangan gereja injili (kharismatik).

Menurut Joseph Prince, Allah yang penuh kasih dan berlimpah kasih karunia, telah melimpahkan karunia kemenangan secara sempurna di dalam Yesus Kristus. Allah yang dilihat sebagai Raja yang telah menjadi pembebas

\footnotetext{
${ }^{1}$ Dalam pengertian umumnya investasi merupakan satu tindakan "pemberian/penanaman modal" yang memiliki tujuan untuk memperoleh keuntungan sebanyak-banyaknya.
} 
secara "sempurna" atas anak-anak-Nya yang masih tinggal di dunia ini. Sempurna dalam pengertian ini, menyatakan bahwa Allah telah mengerjakan karya keselamatan-Nya 2000 tahun yang lalu. Allah sebagai pribadi yang Maha kasih, telah menempatkan secara sempurna anak-anak-Nya dalam pengampunan yang sempurna melalui penghukuman Yesus Kristus. Sehingga anak-anak Allah tidak perlu lagi untuk menyatakan permohonan pengampunan dan tunduk pada ketaatan akan hukum-hukum-Nya.

Karya pengampunan sudah selesai dan saat ini anugerah-Nyalah yang senantiasa menjadi bagian dalam kehidupan orang percaya. Dengan anugerah-Nya yang besar, anak-anak Allah telah menerima otoritas penuh dan seharusnya menjadi penguasa atas kehidupannya, atas pergumulan, atas masalah dan seluruh tantangan. Atas dasar tersebut, maka Joseph Prince menegaskan bahwa umat Allah telah menerima satu panggilan, yaitu "ditentukan untuk berkuasa", dan Prince menegaskan "you are called by the Lord to be a succsess, to enjoy wealth, to enjoy health and to enjoy a life of victory". 2

Demikianlah kemasan baru dari teologi anak Raja, yang menempatkan otoritas anak-anak Allah untuk memerintah dan berkuasa atas kehidupan sebagai raja, memiliki peran sebagai raja, dan untuk memiliki kuasa sebagai raja; berkuasa dan memerintah dengan otoritas atas kemiskinan, kutukan, dan penyakit. Dengan otoritas penuh tersebut maka kesuksesan, kekayaan, dan kesehatan adalah bagian "mutlak" atas diri setiap orang percaya.

\section{Pemerintahan Allah Bersifat Spiritual dan Futuristik}

Sesungguhnya otoritas spiritual memang merupakan bagian yang diberikan Allah sebagai satu perlengkapan dalam memasuki peperangan rohani. Namun, hanya dengan memahami bahwa otoritas dan pemerintahan Allah yang dikaruniakan kepada umat-Nya sejauh otoritas spiritual semata, maka tentunya telah membatasi Allah dalam lingkup spiritual semata dan tidak melihat dunia serta segala aspek dalam kehidupan sebagai bagian yang integral dengan

${ }^{2}$ Joseph Prince, Destined To Reign: The Secret to Effortless Success, Wholeness and Victorious Living (Oklahoma: Harrison House Publishers, 2011). 
spiritual. Pemahaman sempit ini, telah menuntut ketidakmampuan untuk memahami karya Allah secara menyeluruh yang secara intrinsik ada dalam mandat hidup orang percaya. Fokus pengajaran pada kehidupan yang akan datang (futuristik), akan membawa anak-anak Allah yang berkonsentrasi untuk hal spiritual dan futuristik semata. Hal inilah yang dikritik oleh John Driver dan menyatakan bahwa ini merupakan perampokan terhadap metafora kerajaan dari vitalitas dan kekuatannya untuk menginspirasi imajinasi umat Allah. Gambaran Kerajaan Allah diabaikan atau dibentuk kembali menjadi istilah-istilah spiritual dan futuristik. ${ }^{3}$

\section{Mentalitas Kerajaan Adalah Mentalitas Spiritual}

Dalam bagian sebelumnya telah melihat bagaimana anak-anak Allah telah "ditentukan untuk berkuasa". Allah telah memberikan otoritas atas anakanak-Nya dengan segala warisan Ilahi. Searah dengan itu Niko Njotorahardjo mengatakan orang percaya harus memiliki "mentalitas Kerajaan" dalam menjalani kehidupan, yang intinya bagian ini ingin menyatakan bahwa Allah sedang melakukan transformasi besar dalam tubuh Kristus, dan meyakinkan bahwa setiap orang percaya diberi kuasa/otoritas Ilahi untuk mengalahkan dan menaklukan kuasa-kuasa setan, roh jahat, dan anti Kristus. Ungkapan ini memahami doktrin imamat rajani sebagai mentalitas kerajaan dan warisan para reformator yang dapat mengalahkah dunia. ${ }^{4}$ Disini dapat dilihat bagaimana mentalitas kerajaan yang dinyatakan Niko Njotorahardjo dimaknai hanya dalam natur spiritual untuk kepentingan spiritual. Dengan mentalitas kerajaan tersebut, maka melihat ibadah sebagai kepentingan untuk "menghadirkan kerajaan dengan penyembahan kepada Allah." Karena itulah Bram Soei Ndoen melihat ibadah (penyembahan) sebagai satu revolusi kerajaan.

Memahami mentalitas kerajaan dalam pengertian diatas menunjukkan ketidakmampuan untuk menguraikan aspek kerajaan diluar gedung ibadah.

\footnotetext{
${ }^{3}$ John Driver, Gambaran Gereja Dalam Misi, terj. Peter S. Wong (Bandung: STT Bandung, 2010), 78 .

${ }^{4}$ Niko Njotorahardjo, "Refleksi: Bangkitkan Kembali Mentalitas Kerajaan", dalam Tabloid Rohani Tritunggal, (Edisi Perdana, 2013), 24. Lihat juga www.hmministry.com

${ }^{5}$ Bram Soei Ndoen, Kingdom Worship Revolution (Yogyakarta: ANDI, 2011), 25-37.
} 
Padahal, ibadah sejati bukan bermaksud untuk menghadirkan kerajaan Allah, yang seolah-olah hanya dalam persekutuan tersebut 'merasakan' kehadiran Allah. Ibadah sejati adalah penyembahan kepada Allah dalam seluruh dimensi kehidupan, penyembahan yang mewujudkan ketertundukan kepada Allah, belas kasihan dan keadilan bagi sesama manusia. Mark Labberton mengatakan bahwa, "Dunia harus dibaharui sebagian melalui buah dari kehidupan yang diubahkan, yakni hidup yang benar dan adil dalam karakter maupun perbuatan. Ciptaan baru ini sebagian terwujud akibat dampak luar biasa para penyembah yang hidupnya membangun kasih, belas kasihan dan keadilan." Karena menurut Mark Labberton "keadilan dan belas kasihan itu unsur intrinsik dari Allah dan karenanya harus menjadi unsur intrinsik dari sebuah ibadah kepada Allah." 7

\section{PEMERINTAHAN ALLAH DAN OTORITAS UMAT-NYA}

\section{Allah dan Pemerintahan-Nya}

Dalam awal pembahasan ini, kita akan melihat terlebih dahulu pemahaman yang umumnya berkembang dalam memahami pemerintahan dan kerajaan Allah. Seorang teolog Asia, Choan-Seng Song, melihat bahwa inti dari pemberitaan Yesus sesungguhnya adalah pemerintahan Allah, Yesus tanpa pemerintahan Allah adalah Yesus yang tidak lengkap. Menurutnya gereja telah mengalami kekeliruan dengan hanya memberitakan Yesus dan bukan pemerintahan Allah. Bagi Song ini adalah bahaya. Karena pemberitaan Yesus yang demikian akan menghilangkan visi pemerintahan Allah. Keterpisahan memberitakan pemerintahan Allah ini, bagi Song berakibat pada pengkultusan pribadi Yesus, dan ini adalah Kristus yang dikerdilkan. ${ }^{8}$ Song lebih menempatkan istilah pemerintahan Allah adalah lebih tepat ketimbang istilah kerajaan Allah dalam mengartikan basileia. Istilah kerajaan Allah baginya hanya memberikan kesan dan arti akan sistem pemerintahan yang

\footnotetext{
${ }^{6}$ Mark Labberton, Bahaya Ibadah Sejati: Sebuah Panggilan Memerangi Ketidakadilan (Surabaya: Literatur Perkantas Jatim, 2011), 85.

${ }^{7}$ Ibid., 46.

${ }^{8}$ Choan-Seng Song, Yesus dan Pemerintahan Allah (Jakarta: BPK Gunung Mulia, 2010), $19-31$.
} 
otoritarianisme dengan wilayah kekuasaan dan sistem politik tertentu, sedangkan istilah pemerintahan Allah tidak menggambarkan akan pemahaman tentang perbatasan baik dalam politik dan agama. ${ }^{9}$

Song tidak keliru ketika ia menyatakan bahwa iman yang hanya melihat kerajaan Allah sebagai satu tempat penantian, hanya cenderung memperkuat ketidakpedulian sosial dan memperkuat sikap negatif terhadap keterlibatan dalam dunia. ${ }^{10}$ Karena memang demikianlah realitas gereja dan orang percaya umumnya. Namun disisi lain, Song keliru ketika menyatakan bahwa pemberitaan akan Yesus hanya akan menghilangkan visi pemerintahan Allah. ${ }^{11}$ Karena tidak mungkin ada pemerintahan Allah tanpa adanya kerajaan Allah, demikian sebaliknya tidak mungkin ada kerajaan Allah tanpa pemerintahan Allah. Yesus adalah Raja, dengan demikian hanya raja yang memiliki wilayah kekuasaan dan pemerintahanlah yang akan diakui oleh siapapun sebagai Raja. Ia dinobatkan sebagai Raja, oleh Allah sendiri yang menempatkan-Nya duduk disebelah kanan Allah Bapa. Memang inti berita Yesus Kristus adalah pemerintahan (kerajaan) Allah, namun kedua hal tersebut tidak dapat dipisahkan. Karena ada Raja, maka ada satu kerajaan dan pemerintahan.

Pemerintahan Allah didefinisikan oleh Louis Berkhof sebagai "tindakan yang terus berlangsung dari Allah dimana Ia mengatur segala sesuatu secara teleologis sehingga memastikan penyelesaian tujuan ilahi". ${ }^{12}$ Pemerintahan yang menyatakan bahwa Allah adalah Raja dari alam semesta dan pemerintahan yang universal (Maz. 22:28, 29; 103:17-19; Dan. 4:34, 35; 1 Tim. 6:15). ${ }^{13}$ Herman Bavinck juga menegaskan bahwa pemerintahan Allah yang providensial memiliki kekhususan atas umat-Nya, ${ }^{14}$ Ini berbicara akan pemeliharaan umat-Nya. Melalui definisi ini jelas bahwa pemerintahan Allah atas dunia fisik juga dinyatakan atas hukum alam, manusia, dan khususnya orang percaya. Atas dasar inilah maka kita akan melihat beberapa bagian

\footnotetext{
${ }^{9}$ Ibid., 66-67.

${ }^{10}$ Ibid., 30-32.

${ }^{11}$ Ibid.

${ }^{12}$ Louis Berkhof, Teologi Sistematika 1: Doktrin Allah (Jakarta: Lembaga Reformed Injili Indonesia, 1997), 332.

${ }^{13}$ Ibid., 332-333.

${ }^{14}$ Herman Bavinck, Dogmatika Reformed: Allah dan Penciptaan (Surabaya: Penerbit Momentum, 2012), 743.
} 
yang menyatakan bahwa Allah dalam pemerintahan-Nya memberikan otoritas kepada warga kerajaan Allah sebagai bagian dalam pemerintahan Allah, yaitu:

\section{Representatif Pemerintahan Allah}

Kitab Kejadian yang memproklamasikan Allah sebagai Pencipta, telah memperlihatkan kronologis tatanan karya ciptaan Allah yang berpuncak kepada penciptaan manusia dan dilanjutkan dengan mandat bagi manusia atas segala ciptaan-Nya. Panggilan sebagai penatalayan dalam memelihara, mengusahakan, mengolah dan menjaga segala ciptaan dan atas seluruh isinya di bumi.

Penatalayan merupakan hakikat fungsional dari penciptaan manusia. Fondasi dari fungsi tersebut didasarkan atas manusia sebagai imago dei. Dengan gambar dan rupa Allah, Allah memberikan otoritas untuk berkuasa dan menaklukkan. Seluruh karya ciptaan Allah yang ada di muka bumi secara keseluruhan ada dalam otoritas terbatas manusia dalam pengelolaannya. Menurut Bavinck manusia sebagai gambar Allah adalah sebuah karunia dan sebuah mandat. Bavinck mengatakan bahwa:

\footnotetext{
"Gambar Allah adalah sebuah karunia (gabe) dan sebuah mandat (Aufgabe). Gambar Allah merupakan karunia anugerah yang - meskipun tidak layak manusia terima - diberikan kepada manusia pertama langsung pada saat penciptaan, tetapi pada waktu yang sama adalah prinsip yang mendasari dan benih dari perkembangan yang kaya dan mulia. Hanya humanitas di dalam keseluruhannya - sebagai satu organisme yang lengkap, yang disatukan di bawah satu kepala, yang tersebar di seluruh bumi, sebagai nabi yang memberitakan kebenaran Allah, sebagai imam yang mendedikasikan dirinya kepada Allah, sebagai penguasa yang mengatur bumi dan seluruh ciptaan - hanya humanitas inilah gambar yang telah selesai sepenuhnya, rupa Allah yang paling jelas dan memukau."15
}

Kita dapat melihat ketiga aspek jabatan yang dinyatakan Alkitab dan termuat dalam penjelasan Bavinck bahwa manusia sebagai nabi, imam dan raja (penguasa). Ketiga aspek yang menegaskan humanitas sebagai gambar Allah. Manusia sebagai gambar dan rupa Allah, merupakan pribadi yang unik

\footnotetext{
${ }^{15}$ Ibid, 725 .
} 
sebagai makhluk yang memiliki gambar Allah yang membedakan dengan makhluk hidup ciptaan lainnya. Manusia merupakan keberadaan yang bepribadi dan bertanggung jawab, yang mampu membuat keputusan dan memerintah. Atas dasar gambar dan rupa Allah, manusia menerima kuasa atas seluruh makhluk hidup, dan juga atas seluruh bumi. Dengan kuasa yang menaklukkan dalam kepenatalayanan, bukan dalam eksploitasi dan penjarahan. Istilah "berkuasa" yang berasal dari kata וִיְִרָּו yang dalam bentuk kata kerja berarti "have dominion, rule, dominate". ${ }^{16}$ Manusia memiliki kuasa untuk mengatur segala ciptaan, manusia sebagai gambar Allah adalah representatif Allah di muka bumi.

Selain itu, Wayne Grudem juga melihat aspek-aspek dalam makna segambar dengan Allah yaitu aspek moral, aspek spiritual, aspel mental, aspek relasional, dan aspek jasmani. Dalam berbicara aspek relasional Grudem menempatkan manusia secara khusus dalam relationship-nya dengan fungsi untuk menenteramkan ciptaan, Grudem menyatakan bahwa, "man has been given the right to rule over the creation and when Christ returns will even be given authority to sit in judgment over angels" (1 Kor. 6:3; Kej. 1:26; Maz. 8:6-8). ${ }^{17}$ Cornelius Plantinga Jr. Juga melihat bahwa Allah memberikan otoritas untuk berkuasa (dominion) bukan untuk menaklukkan, yang ia sebut sebagai responsible dominion. Allah sebagai Raja atas alam semeta menempatkan sub-kingdoms dibawah-Nya. Dominion yang lebih dipahami sebagai stewardship. Plantinga juga menjelaskan bahwa sama seperti Yesus yang memproklamasikan Kerajaan Allah, dominion tidak pernah "lording over" tetapi lebih kepada "lording under". Dominion yang bertindak sebagai mediator ciptaan. Inilah yang dimaksudkan bahwa penatalayanan umat manusia tidak pernah merupakan eksploitasi atau penjarahan. Plantinga menegaskan bahwa "this means that a human steward of God's good creation will never exploit or pillage; instead, she will give creation room to be itself. She will respect it, care for it, empower it. Her goal is to live in healthy interdependence with it." ${ }^{\text {"18 }}$

\footnotetext{
${ }^{16}$ Brown Driver Briggs, diakses dari http://biblehub.com/bdb/7287.htm pada tanggal 6 Mei 2015.

${ }^{17}$ Wayne Grudem, Systematic Theology: An Introduction to Biblical Doctrine (Nottingham: InterVarsity Press, 1994), 448.

${ }^{18}$ Cornelius Plantinga Jr. Engaging God's World: A Christian of Faith, Learning, and Living (Grand Rapids: William B. Eerdmans Publishing Company, 2002), 31.
} 
Selain itu, Anthony Hoekema juga memahami bahwa Kej. 1:26 yang memuat bagian "beranak cuculah dan bertambah banyak; penuhilah bumi." Merupakan berkat Allah yang mengandung perintah atau mandat. Inilah yang dikatakan sebagai mandat budaya: perintah untuk memerintah bumi atas nama Allah dan membangun budaya yang memuliakan Allah. ${ }^{19}$

Kebudayaan dalam cakupan keseluruhan aspek kehidupan manusia, menekankan kepenatalayanan global atas manusia terhadap segala ciptaan-Nya. Kuasa untuk mengelola alam ciptaan dan segala isinya. Manusia sebagai gambar dan rupa Allah, sudah diciptakan dengan gambar Allah untuk mengelola dengan karakter ilahi untuk tujuan Allah dan bukan tujuan pengelolaan atas kehendak manusia sendiri. Fungsi global sudah diemban manusia sejak awal penciptaan, untuk melayani dan mengatur. Dengan demikian teranglah bahwa dalam penciptaan manusia sebagai gambar dan rupa Allah, sudah memikul tanggung jawab sebagai penatalayan global, seluruh aspek kehidupan di dunia dalam kuasa pengaturan dan pengelolaan manusia.

Manusia ditempatkan untuk keterlibatan dalam pemerintahan Allah di muka bumi, memerintah dengan melayani sebagai representatif Allah. Melayani dengan dan sebagai cermin dari karakter ilahi. ${ }^{20}$ Untuk mewujudnyatakan pemerintahan Allah atas segala ciptaan-Nya. TUHAN Allah, Sang Raja Agung mendelegasikan otoritas-Nya atas manusia ciptaan-Nya untuk memerintah, menguasai dan mengatur. Manusia sebagai raja-raja yang otoritasnya diterima dari pemberian Allah, dengan demikian ini menjadi fondasi kokoh bagi panggilan kepenatalayanan untuk pemerintahan Allah atas permasalahan global di muka bumi ini.

\section{Visi Global Pemerintahan Allah}

Kejatuhan manusia di dalam dosa yang menuntun pada janji keselamatan Allah kepada umat-Nya, merupakan sejarah keselamatan yang ada di dalam dan melalui sejarah, keselamatan tersebut diwujudkan dalam prosesnya.

\footnotetext{
${ }^{19}$ Anthony A. Hoekema, Manusia: Ciptaan Menurut Gambar Allah (Surabaya: Penerbit Momentum, 2008), 20.

${ }^{20}$ Stanley J. Grenz. Theology For The Community of God (Grand Rapids: William B. Eerdmans Pub. Co., 1994), 177-178.
} 
Karya pemilihan yang Allah sejarahkan dimulai dalam kehidupan diri Abraham. Satu janji visional yang bukan hanya menyangkut satu umat dalam keterbatasan suku bangsa dan wilayah, tetapi merupakan komunitas yang melampaui suku bangsa, bahasa dan wilayah dalam tujuan kekekalan.

Dalam Kej. 12:1-3, sudah diekspresikan satu dimensi universal dari iman Israel. Janji yang paralel dengan Kej. 18:18 dan 28:14. Seperti yang dikatakan Eckhard J. Schnabel, "Israel's "story" clearly incorporates a universal dimension, as her identity is intimately linked with Abraham's call and the divine promise of blessing which is extended to "all the families of the earth." 21 Dalam Kej. 28:14 yang menegaskan bahwa, "keturunanmu akan menjadi seperti debu tanah banyaknya, dan engkau akan mengembang ke sebelah timur, barat, utara dan selatan, dan olehmu serta keturunanmu semua kaum di muka bumi akan mendapat berkat". Bagian ini merupakan satu janji rekonfimasi dari mandat budaya, beranak cucu dan penuhilah bumi. Ini merupakan janji bahwa keturunan Abraham (secara rohani) akan menjadi pembawa berkat bagi umat manusia yang telah kehilangan berkat Allah akibat dosa.

Janji Allah kepada Abraham adalah menjadi bangsa yang memiliki kuasa dan menjadi berkat untuk segala bangsa di atas bumi (Kej. 18:8). Nabi Yesaya juga dalam pasal 49:6, mengatakan bahwa, "Terlalu sedikit bagimu hanya untuk menjadi hamba-Ku, untuk menegakkan suku-suku Yakub dan untuk mengembalikan orang-orang Israel yang masih terpelihara. Tetapi Aku akan membuat engkau menjadi terang bagi bangsa-bangsa supaya keselamatan yang dari pada-Ku sampai ke ujung bumi." Hal ini dikutip oleh Paulus sebagai penggenapan apa yang dinubuatkan oleh nabi Yesaya. Paulus menuliskan bahwa, "Yesus Kristus telah membuat ini, supaya di dalam Dia berkat Abraham sampai kepada bangsa-bangsa lain, sehingga oleh iman kita menerima Roh yang telah dijanjikan itu" (Gal.3:14).

Inilah yang merupakan satu visi global yang mencakup berkat keselamatan yang Allah berikan didalam dan melalui Yesus Kristus, menurut David F. Wells. ${ }^{22}$ Visi Allah yang dinyatakan melalui Abraham dan tergenapi

\footnotetext{
${ }^{21}$ Eckhard J. Schnabel, "Israel, The People of God, and The Nations" dalam Journal of the Evangelical Theological Society, 45/1 (March 2002): 35-36.

${ }^{22}$ David F. Wells, "Christian Dischipleship in a Postmodern World" dalam Journal of the Evangelical Theological Society, 51/1 (March 2008): 32.
} 
di dalam diri Yesus Kristus. Terang atas bangsa-bangsa (Abraham), dan Yesus adalah terang dunia (Yesus), dan Yesus memandatkan orang percaya untuk menjadi terang dunia. Terang yang tidak tersembunyi dalam ketertutupan gantang, tetapi terang di atas suatu tempat yang menerangi sekelilingnya.

Visi global pemerintahan Allah, didalam Perjanjian Lama telah dimulai dengan pembentukan bangsa terpilih, yaitu umat Israel. Umat yang dipisahkan dan dikuduskan, untuk dapat menyatakan terang ilahi bagi bangsa lain. Pemerintahan teokrasi bangsa Israel, juga sebagai tipologi dari pemerintahan Allah yang digenapi dalam Yesus Kristus. Bahwa takhta Daud akan kekal selamanya, dan itu hanya tergenapi dalam pemerintahan Yesus Kristus sebagai Raja atas umat-Nya, sekarang dan yang akan datang.

Dari perspektif studi sejarah, Andrew F. Walls melihat bahwa keselamatan sebagai suatu proses historis dengan memberikan dua implikasi, yaitu tujuan penebusan Allah adalah lintas generasi (cross-generational) dimana keselamatan yang dijanjikan Allah bukan hanya untuk Abraham tetapi juga untuk generasi kita saat ini, bukan hanya lengkap untuk generasi di masa inkarnasi Kristus tetapi juga hingga masa-masa yang akan datang (KPR 2:39). Implikasi kedua, lintas budaya (cross-cultural) sebagai difusi kekristenan. Walls menegaskan bahwa "since then Christian cross-cultural diffusion has brought many more into the church, and our own day has seen the greatest proliferation of all". ${ }^{23}$ Kekristenan sudah selalu dalam prinsip global. Bukan hanya fenomena di abad 21 ini. Visi global yang disertai keyakinan otoritas, menjadi penggerak bagi para murid untuk pergi memberitakan Injil ke daerah lain. Ini adalah pergerakan penginjilan yang telah memulai akar-akar pengaruhnya bagi globalisasi di masa itu.

\section{Otoritas Supra-Global Pemerintahan Allah}

Proklamasi Yesus Kristus yang menyatakan bahwa segala kuasa ${ }^{24}$ baik di bumi dan di surga telah diberikan kepada-Nya (otoritas supra-global), bukan

${ }^{23}$ Andrew F. Walls, "Globalization and the Study of Christian Church" dalam Globalizing Theology: Belief and Practice in an Era of World Christianity, Ed. Craig Ott dan Harold A. Netland (Grand Rapids: Baker Academic, 2006), 73.

${ }^{24}$ Otoritas (kuasa) yang diterjemahkan dari kata $\varepsilon \xi$ ov $1 \alpha$ yang diartikan sebagai otoritas. Thayer's Greek Lexicon, diakses dari http://biblehub.com/bsoft.htm pada tanggal 8 Mei 2015. 
hanya ingin meyakinkan para murid untuk pergi memberitakan Injil dan menjadikan segala bangsa murid-Nya, namun terkandung juga konfirmasi bahwa Yesus Kristus juga memberikan otoritas bagi orang percaya yang ada dalam pemerintahan Allah untuk kembali dalam otoritas semula (Kej. 1:26, 28) sebagai manajer Allah atas kehidupan manusia (berita Injil), atas alam semesta (keharmonian) dan penjagaan serta pemeliharaan seluruh aspek kehidupan manusia yang tidak dapat dipisahkan satu dengan lainnya (interkoneksi) dalam alam semesta ini.

Keuniversalan otoritas Kristus tidak serupa dengan otoritas manusia dalam mengelola karya ciptaan Allah. Otoritas yang tidak hanya di bumi tetapi juga di surga, otoritas atas dunia (global) dan atas surga. Di bumi dan di surga menyatakan keseluruhan kuasa diatas segala kuasa, bahwa Yesus adalah Raja Agung atas bumi dan surga. Dalam memahami otoritas tersebut terdapat perbedaan esensial dalam kedua otoritas, manusia di beri kuasa untuk menaklukkan seluruh bumi, dan tidak dengan surga, sedangkan Yesus adalah Tuhan dan Raja yang bukan hanya bumi, tetapi juga surga (supra-global).

Dengan otoritas supra-global itu, Yesus mengutus para murid untuk menjadi saksi sampai ke ujung-ujung bumi, melengkapi dan mengingatkan akan amanat dalam Kejadian. Karena itulah kita juga dapat memahami bahwa Matius 28:19, merupakan pengutusan manusia baru yang telah dipulihkan atas dosa. Jika pengutusan pertama berlaku atas Adam, untuk seluruh bumi dan segala ciptaan lainnya. Pengutusan kedua diberikan Yesus Kristus atas umat-Nya untuk membawa kembali umat yang terhilang dalam persekutuan dengan-Nya yang juga akan menjadi pemulihan otoritas atas bumi dan segala isinya. Ini merupakan pengutusan restorasi.

Pemahaman tentang Pemerintahan Allah dalam Perjanjian Baru didasarkan atas dasar bahwa Yesus Kristus adalah Raja. Umat Allah sebagai komunitas tebusan melalui pengorbanan Yesus Kristus, yang dilahirkan dalam karya Roh Kudus telah dimeteraikan dengan Roh-Nya sebagai milik kepunyaan Allah yang akan hidup dibawah bimbingan Roh Kudus. Umat Allah sebagai komunitas global memberikan makna sebagai persekutuan orang percaya yang telah dipilih dan dipanggil oleh Allah melalui penebusan tubuh dan darah Yesus Kristus melampaui batasan suku, bangsa, wilayah dan bahasa; 
untuk menjadi saksi bagi dunia secara global. Kata sifat "global" menunjukan bahwa komunitas orang percaya memiliki tanggung jawab menjadi saksi dalam keseluruhan aspek kehidupan dan keberadaan di dunia. Jika dikatakan bahwa umat Allah sebagai komunitas global, maka hal itu menekankan pada atribut fungsional umat Allah yang am untuk mendunia yang memperlihatkan aksi nyatanya di dunia dalam seluruh aspek kehidupan.

\section{Otoritas Umat Allah sebagai Bagian Pemerintahan Allah}

Dalam naturnya, gereja adalah Am atau universal, yang merupakan kesatuan orang percaya seluruh penjuru dunia yang berlaku sepanjang sejarah. Persekutuan yang tidak dibatasi dengan denominasi, suku, bahasa dan daerah. ${ }^{25}$ Tetapi merupakan persekutuan yang menunjukkan kesatuan orang percaya. Persekutuan Am yang dipanggil dan dipilih untuk menjadi garam dan terang di tengah dunia global, sebagai globalizer.

Anak-anak Allah di utus ke dunia dengan panggilan global (Yoh. 17:18). Jika dalam penatalayanan global menunjukkan luasnya yang tak terbatas dalam kehidupan amanat orang percaya, maka itu juga menunjukkan mandat baginya ditempat dimana ia berdiri. Mandat yang berlaku secara individual dimana seseorang berdiri, namun mandat global atas Adam dan keturunannya. Artinya mandat itu berlaku universal yang dikerjakan individu-individu dalam hakekatnya sebagai makhluk sosial yang tidak dapat menampik kebersamaan untuk mewujudkan mandatnya sebagai globalizer. Melaksanakan pemuridan yang bukan hanya menjadi orang percaya, tetapi membangun murid dengan perspektif global, integratif, holistik dan transformatif.

Anak-anak Allah yang telah memiliki otoritas global, semestinya juga memiliki perspektif global untuk dapat berfungsi sebagai globalizer, ${ }^{26}$ dalam panggilannya sebagai garam dan terang dunia. Menggarami seluruh aspek kehidupan manusia seperti panggilan sediakala dalam diri Adam dan untuk

\footnotetext{
${ }^{25}$ Louis Berkhof, Teologi Sistematika 5: Doktrin Gereja (Jakarta: Lembaga Reformed Injili Indonesia, 1997), 23.

${ }^{26}$ Dalam bagian ini, istilah "globalizer" merupakan bentuk kata benda yang merujuk kepada individu atau komunitas orang percaya yang menjadi pembawa pengaruh iman kekeristenannya dalam segala aspek-aspek kehidupan secara global. Dengan kehidupan iman yang kokoh, mendemonstrasikan buah imannya dalam seluruh aspek kehidupan. Istilah yang digunakan dalam Lausanne Occasional Paper 30.
} 
menjadi terang yang mampu menyingkapkan dan menyingkirkan segala sisi kegelapan, sehingga manusia dapat menemukan panggilan sejatinya karena telah diterangi oleh karya Roh Kudus. Tentunya ini menepis pandangan kebiasaan anak-anak Allah yang hanya cenderung berpikir lokal dan intern, menutup mata dan apatis terhadap dunia sekitar, sehingga tanpa disadari sudah memberangus fungsi globalizer anak-anak Allah di tengah arus globalisasi.

Menegaskan fungsi globalizer, dokumen Lausanne Occasional Paper No. 30 menegaskan bahwa anak-anak Allah merupakan komunitas yang memiliki cara yang hidup untuk menceritakan sebuah bagian cerita tentang realitas. Dimana anak-anak Allah eksis untuk mendorong dan mengimplementasikan penebusan melalui partisipasi dalam sejarah ini yang berpusat pada Yesus Kristus. Dan atas perannya sebagai globalizer, umat Allah dapat menjadi pengendali globalisasi dalam sejarah dunia.

\section{PERAN UMAT ALLAH DALAM MENYONGSONG MASYARAKAT EKONOMI ASEAN (MEA)}

\section{Sekilas Tentang MEA}

Era globalisasi sebagai latar belakang yang mendorong komunitas masyarakat ASEAN ingin semakin mewujudkan visinya (one vision, one identity, one community). Era globalisasi yang ditandai dengan era informasi tak dapat terbendung lagi. Karena itu masyarakat ASEAN mewujudkan mimpi mereka dan merespon tuntutan dengan merancang dan memberlakukan MEA. Dengan melihat suatu pasar dari sekitar 500 juta orang penduduk ASEAN dan memasuki abad 21 para pemimpin menandatangani piagam ASEAN vision 2020. Satu visi yang mengharapkan: 1) bahwa zona ASEAN menjadi suatu zona yang damai, merdeka dan netral seperti yang sudah digambarkan dalam deklarasi tahun 1971. 2) suatu kerja sama dalam perkembangan yang dinamis melalui integrasi ekonomi. Ketiga, suatu komunitas yang saling mempedulikan yang mempertahankan harkat dan martabat kemanusiaan dalam komunitas ASEAN. 3) mengharapkan ASEAN dapat memainkan perannya di dunia internasional. ${ }^{27}$

\footnotetext{
${ }^{27}$ http://www.asean.org/news/item/asean-vision-2020 di akses tanggal 2 Mei 2015.
} 
Deklarasi percepatan implementasi Komunitas Ekonomi ASEAN yang kemudian menjadi Masyarakat Ekonomi ASEAN, telah dipersiapkan dengan penyusunan blueprint MEA yang ditandatangani oleh para pemimpin negara pada tanggal 20 November di 2007 di Singapura. MEA sendiri memiliki empat pilar utama, yaitu: Pertama, menjadikan ASEAN sebagai pasar tunggal dan pusat produksi. Kedua, menjadi kawasan ekonomi yang kompetitif. Ketiga, menciptakan pertumbuhan ekonomi yang seimbang. Keempat, integrasi ke ekonomi global. sedangkan dalam mengembangkan pilar pertama bahwa ASEAN sebagai pasar tunggal dan basis produksi memiliki lima elemen utama, yaitu aliran bebas barang, jasa, investasi, modal dan tenaga kerja terampil. $^{28}$

Dengan dicanangkannya integrasi ekonomi masyarakat ASEAN, tentunya memberikan tantangan dan peluang yang sekaligus merupakan dampakdampak yang pasti tak terhindarkan ada dan akan muncul dalam pelaksanaan MEA. Dalam studi dan kajian-kajian awal yang telah banyak dilakukan oleh para ahli dan juga lembaga pemerintah, misalnya dalam kajian Lemhannas mengungkapkan bahwa ada 3 point yang menjadi permasalahan dalam MEA, yaitu:1) kesenjangan ekonomi antar negara ASEAN yang dapat mengganggu proses integrasi ekonomi. 2) Indonesia sebagai negara yang memiliki ukuran ekonomi terbesar juga memiliki permasalahan kesenjangan yang tinggi dalam ekonomi dan sosial di dalam negeri. 3) perkembangan ASEAN Framework on Equitable Economic Development berjalan lambat dan lemahnya komitmen negara-negara ASEAN. ${ }^{29}$ Selain itu, Lemhannas melihat bahwa tantangan yang muncul disebabkan oleh proteksionisme dan tingginya persaingan diantara negara ASEAN, perbedaan politik, budaya, bahasa, agama, pendapatan masyarakat dan sistem ekonomi. ${ }^{30}$

Asianfarmers sebagai asosiasi penggiat dalam bidang pertanian di Asia, juga menanggapi bahwa pemberlakuan MEA hanya akan bermanfaat bagi

${ }^{28}$ Direktorat Jenderal Kerjasama ASEAN, ASEAN Economic Community Blueprint (Jakarta: Departemen Luar Negeri, 2009). Diakses dari http://www.smecda.com/Files/Asean/ Cetak\%20Biru\%20 Komunitas\% 20Ekonomi\%20ASEAN.pdf., pada tanggal 10 Mei 2015.

${ }^{29}$ Jurnal Kajian Lemhannas, Peningkatan Peran Indonesia dalam ASEAN Framework On Equitable Economic Development (EED) dalam rangka Ketahanan Nasional, Edisi 16 (November 2013): 58. Diakses dari www.lemhannas.go.id pada tanggal 10 Mei 2015.

${ }^{30}$ Ibid. 
pelaku ekonomi dan bisnis besar yang memiliki posisi dan peluang sangat besar untuk mendapatkan keuntungan dari proyek-proyek besar yang dirancangkan dalam blueprint MEA. Tetapi bagi pelaku ekonomi, bisnis dan produsen kecil kurang mendapatkan kebijakan dan keuntungan. Tenaga kerja yang disebutkan dalam blueprint MEA hanyalah kalangan professional dan berketerampilan tinggi. ${ }^{31}$ Sehingga ini hanya menjadi keuntungan dan kemakmuran sepihak, tetapi masyarakat dan produsen kecil akan tetap terpinggirkan dan sulit untuk menikmati program ini. Selain itu, pemerhati Asianfarmers juga melihat bahwa liberalisasi perdagangan dan investasi dapat berdampak negatif pada ekonomi dan pengerahan tenaga kerja lokal. Dengan melihat akan banyaknya penelitian yang meragukan bahwa liberalisasi dapat membawa dampak pada peningkatan ekonomi. ${ }^{32}$ Akhirnya Asianfarmers menegaskan kritik dan evaluasinya bahwa memang program ini menamakan sebagai "komunitas", tetapi dari bluepritnya tidak menunjukkan keberadaan kehidupan sebagai komunitas?. ${ }^{33}$ Integrasi ekonomi bagi sebagian masyarakat dapat menjadi manfaat yang menguntungkan, sedangkan bagi kebanyakan juga menjadi ancaman ekonomi yang dapat meningkatkan kesenjangan antara pemenang dan yang kalah.

Melihat latar belakang, sasaran dan kesempatan serta tantangan yang ada dalam pemberlakuan MEA tsb, maka ada berbagai peran yang dapat dinyatakan oleh umat Allah sebagai bagian pemerintahan Allah untuk mewujudkan prinsip-prinsip pemerintahan Allah yang menjawab pergumulan MEA, diantaranya:

\section{Mensosialisasikan MEA}

Dalam sosialisasinya, sebenarnya MEA sendiri masih asing bagi kebanyakan masyarakat (sangat besar kemungkinan juga bagi gereja dan warganya) diberbagai daerah, pelosok dan pedalaman, namun sesungguhnya tanpa disadari dampaknya akan terasa langsung bagi seluruh lapisan masyarakat.

\footnotetext{
${ }^{31} \mathrm{http}: / /$ asianfarmers.org/wp-content/uploads/2008/07/indonesia-bahasa.pdf diakses 1 Mei 2015 ${ }^{32}$ Ibid.

${ }^{33} \mathrm{Ibid}$.
} 
Tentunya hal ini menjadi tugas pemimpin gereja untuk mengkomunikasikannya, sehingga dapat mengajarkan kebenaran antisipatif atas arus globalisasi khususnya MEA. Masih menggunakan data survey tahun 2012, Kementerian Luar Negeri merincikan bahwa masih $76 \%$ penduduk Indonesia belum familiar dengan Masyarakat ASEAN, ini memperlihatkan akan ketidakmampuan pemerintah bekerja sendiri dan yang sangat membutuhkan gerakan sporadik dari berbagai pihak (termasuk gereja) untuk membangun kesadaran masyarakat akan pemberlakuan MEA. ${ }^{34}$

\section{Menciptakan SDM Unggul}

Dengan bebasnya arus perekonomian dan tenaga kerja, maka semakin meningkatnya daya saing dalam dunia kerja, di daerah atau negara sendiri sekalipun. M. Nasir, Menteri Pendidikan Tinggi, Riset dan Teknologi mengungkapkan satu keprihatinan bahwa hanya $30 \%$ dari penduduk Indonesia (usia 19-23 tahun), yang memiliki pendidikan sarjana (S-1). ${ }^{35}$ Itu berarti Indonesia sendiri masih memiliki tenaga kerja terampil dan berpendidikan yang sangat terbatas, dan $70 \%$ lainnya sangat riskan dalam pergulatan daya saing dengan tenaga kerja dari negara lainnya. Terlebih lagi dinegara-negara ASEAN tenaga kerja (buruh) ASEAN sudah belajar bahasa Indonesia. ${ }^{36}$ Daya saing SDM merupakan syarat mutlak untuk membuka seluruh peluang dalam MEA. Dengan demikian dibutuhkan sinergi atas seluruh pemangku kepentingan untuk meningkatkan daya saing professional; baik pemerintah, dunia pendidikan, perguruan tinggi, praktisi, pelaku usaha, ${ }^{37}$ termasuk peran aktif umat Allah.

Dalam menjawab pergumulan MEA 2015 umat Allah yang telah menerima otoritas dari pemerintahan Allah semestinya dapat menjadi agen

\footnotetext{
${ }^{34}$ Lih. Adhy Buwono Putro, Memetik Manfaat Nyata MEA" dalam Majalah Masyarakat ASEAN, Media Komunikasi Direktorat Jenderal Kerjasama ASEAN, Edisi 7 (Maret 2015):14. Diakses dari http://www.kemlu.go.id/Magazines/ASEAN-7-2015.pdf pada tanggal 5 Mei 2015.

${ }^{35}$ http://news.detik.com/berita/2925475/menteri-nasir-perguruan-tinggi-online-yang-ada-i zin-cuma-satu di akses 26 Mei 2015.

${ }^{36}$ http://www.bbc.co.uk/indonesia tanggal 27 Agustus 2014; http://bisnis.liputan6.com/ read/2223885/ hadapi-mea-buruh-asean-mulai-belajar-bahasa-indonesia, diakses 1 mei 2015.

${ }^{37}$ Iwan Suyudhie Amri, "MEA, Peluang Bersyarat" dalam Majalah Masyarakat ASEAN, 4-5.
} 
pembaharuan dalam pola pikir dan praktek kehidupannya. Data diatas semestinya membuka mata hati anak-anak Allah (gereja) untuk bergandengan tangan memberikan bantuan pendidikan kepada anak-anak muda yang potensial (setidak-tidaknya pemuda gereja), supaya dalam keterbatasan ekonomi anak-anak muda ini dapat mengembangkan potensinya dan kelak menjadi SDM yang unggul dan handal. Selain bantuan pendidikan, gereja juga mesti lebih respek lagi dalam memberikan penyuluhan kepada kaum muda, supaya memiliki kekayaan spiritual yang bertumbuh. Sehingga pada saatnya mereka memasuki dunia kerja, anak muda gereja sungguh-sungguh siap menghadapi tantangan konkrit, dan mampu memancarkan fungsi globalizer. Sesungguhnya, banyak hal yang dapat dilakukan gereja dalam mengembangkan usia muda menjadi tenaga terampil dan professional; baik dengan pembinaan spiritual, bantuan pendidikan formal, pelatihan-pelatihan berwiraswasta dan sebagainya.

\section{Mendorong Terciptanya Ekonomi Kreatif}

Dalam otoritas dan perannya sebagai bagian pemerintahan Allah di tengah dunia, orang percaya sebagai globalizer berperan dalam kehadirannya untuk menciptakan oase kehidupan sehingga memperkecil kesenjangan dan menghadirkan kesegaran hidup dalam seluruh aspek positif dan negatif dari pelaksanaan MEA. ${ }^{38}$ Ekonomi kreatif merupakan salah satu program unggulan pemerintah, dalam memberdayakan ekonomi masyarakat. Pemberdayaan yang mengeksplorasi daya kreatifitas untuk menjadikan setiap potensi yang telah Allah tempatkan dalam lingkungan. Dengan tingginya daya saing tenaga kerja, maka dapat disiasati dengan keterlibatan gereja dalam mengembangkan ekonomi kreatif bagi warga jemaatnya atau masyarakat

\footnotetext{
${ }^{38}$ Lihat dalam Jonathan Parapak, "Gereja-gereja Di Indonesia Menyongsong Era Informasi” dalam Gerakan Oikumene Tegar Mekar di Bumi Pancasila (Jakarta: BPK Gunung Mulia, 2012), 335-6. Menurutnya gereja mesti mempersiapkan diri sebagai inspirator pengarah dan hati nurani dari masyarakat informasi. Gereja memiliki peran menjadi inspirator dan oase dalam lingkungan masyarakat yang padat teknologi. Jonathan Parapak melanjutkan bahwa akan meningkatnya kemajemukan masyarakat dan anggota gereja. Kemajemukan yang bukan lagi berbicara suku, agama, profesi dan hobi; tetapi kemajemukan yang ditampilkan oleh adanya kesenjangan antara yang memiliki informasi dan tidak, antara gaya hidup canggih dan tradisional. Menurut Parapak dalam hal ini gereja ditantang untuk memberikan pelayanan yang relevan dan mampu memperkecil kesenjangan-kesenjangan tersebut.
} 
disekitarnya. Kesediaan persekutuan anak-anak Allah untuk terlibat dalam hal ini, menunjukkan akan kesejatian mentalitas kerajaan. Turut serta memperbaiki ekonomi masyarakat kecil, dan menjembatani kesenjangan dalam sosial ekonomi warga gereja dan masyarakat. Tantangan dan tingginya daya saing hidup, mesti diwaspadai. Ketika gereja tidak mampu menyiapkan tenaga yang berdaya saing tinggi, maka akan menciptakan permasalahan baru dalam gereja. Gereja perlu meningkatkan kepekaan dalam mengeksplorasi seluruh potensi yang ditempatkan disekitarnya, baik warga juga alam dengan kearifan lokal demi tercapainya fungsi globalizer untuk mensejahterakan kehidupan warganya.

\section{Mewujudkan Pendidikan Integratif dan Holistik}

Otoritas Allah yang dikaruniakan kepada anak-anak-Nya tidak dapat dilihat hanya sebagai otoritas spiritual dalam menaklukan kejahatan spiritual di muka bumi ini. Demikian juga otoritas yang di terima warga kerajaan Allah bukan hanya untuk mengalahkan tantangan dan pergumulan seperti yang diajarkan Joseph Prince, demi mendapatkan kesuksesan, kesehatan dan kemakmuran. Namun otoritas yang diterima umat Allah adalah otoritas global, yang mencakup seluruh aspek kehidupan, jasmani dan rohani. Keduanya adalah keutuhan yang tidak dapat terpisahkan. Karena itu, otoritas untuk menjadi agen pembaharuan yang bertindak sebagai penatalayan global untuk menyatakan pemerintahan Kerajaan Allah di muka bumi ini, dapat diwujudkan salah satunya melalui pendidikan yang integratif dan holistik.

Dengan melihat sisi dunia pendidikan, lembaga-lembaga pendidikan Kristen memiliki tanggung jawab penuh dalam melakukan pembaharuan paradigma untuk berpikir dan bertindak secara integratif dan holistik. Dalam menghadapi tantangan globalisasi, hasil Kongres Ketiga Lausanne yang dirumuskan dalam The Cape Town Commitment ${ }^{39}$ menegaskan bahwa, dalam pendidikan Kristen (sekolah dan universitas), memiliki tanggung jawab untuk

${ }^{39}$ Lih. Bab 1 point 7 dari The Third Lausanne Congress on World Evangelization: The Cape Town Commitment, hal. 195. The Cape Town Commitment: A Confesion of faith and a call to action, The Third Lausanne Congres on World Evangelization, 1 Oktober 2010 diakses dari www.lausanne. Org/ctcommitment tanggal 4 Mei 2015. 
mengajar dan mengembangkan disiplin ilmu dari wawasan dunia alkitabiah yang dapat mempengaruhi seluruh subjek pembelajaran mereka.

Dengan berpusatkan Kristus, berkomitmen dalam keunggulan akademik dan kebenaran Alkitab. Khususnya juga, seminari teologi sebagai pencetak para pemimpin gereja, merupakan wadah untuk melatih jiwa para hamba Tuhan dan menjadi jantung pendidikan Kristen dan pemimpin gereja. Lembaga pendidikan Kristen akan menjadi hati nurani bagi masyarakat, khususnya gereja. Dengan paradigma pendidikan yang holistik, maka akan menempatkan orang-orang percaya dalam peluang yang besar untuk bergerak melakukan seluruh perkerjaannya dengan leluasa di berbagai lapisan masyarakat, bahkan lintas budaya dan negara. Paradigma yang integratif dan holistik sebagai keniscayaan dalam menjawab permasalahan global, yang harus dapat meresap dalam seluruh fondasi kehidupan.

\section{Mempererat Kemitraan}

Dalam menunaikan panggilannya sebagai globalizer, tubuh Kristus semestinyalah menjalin kerja sama antar gereja dalam memperluas jaringan antar persekutuan anak-anak Allah dan dalam peningkatan sumber daya manusia. Gereja-gereja Tuhan perlu membangun partnership untuk menunaikan tugas yang memiliki jangkauan sangat luas ini. Dalam hal kemitraan gereja tersebut Vinay Samuel menegaskan bahwa gereja seharusnya menjadi model, Vinay Samuel menuliskan bahwa "The church should be a model community where the Spirit enables the kingdom to become visible in all human relations and systems, through individual, family and community relations". ${ }^{40}$ Jelaslah bahwa pemerintahan Allah harusnya terlihat atas setiap relasi dan kehidupan umat manusia, dan gereja sebagai komunitas global ${ }^{41}$ memiliki tanggung jawab tersebut. Jika kita kembali melihat dalam Laussanne Occasional Paper

\footnotetext{
${ }^{40}$ Vinay Samuel, "Evangelical Response to globalization: an Asian Perspective" dalam Transformation 16/1 (1999): 7.

${ }^{41}$ Kendati ada banyak fenomena keberagaman dalam gereja, namun bagi Todd Johnsonn keberagaman tersebut merupakan fenomena kekristenan global. Todd Johnson dan Sandra S.K.Lee, "From Western Christendom to Global Christianity" dalam Perspectives: On The World Christian Movement, ed. Ralph D. Winter and Steven C. Hawthorne (Pasadena: William Carey Library, 2009), 392.
} 
30, maka kita juga melihat bawah tubuh Kristus dalam keberagamaannya, satu didalam Roh kudus yang memiliki berbagai karunia dan talenta untuk melayani Tubuh Kristus. Dengan demikian gereja memiliki panggilan untuk mengutus profesional Kristen dalam berbagai aspek kehidupan dunia. ${ }^{42}$ Gereja sebagai persekutuan anak-anak Allah yang harus menjadi model bagi masyarakat global, semestinyalah untuk membangun kemitraan dan menyadari bahwa hal ini sebagai panggilan bersama seperti ajakan yang didengungkan dalam Lausanne Occasional Paper, menyatakan "we are called, clergy and laity, individually and collectively, globally and locally, to bear witness to his sovereign rule and his unfathomable love." 43

\section{Membangun Budaya (hidup) Sederhana}

Kesejatian identitas diri sebagai warga kerajaan Allah dalam era MEA semakin ditantang dengan life-style budaya globalisasi yang cenderung konsumtif dan hedonistik. ${ }^{44}$ Untuk itu fungsi globalizer, semestinya dapat menanamkan nilai-nilai kesederhanaan, yang tidak menjadi serupa dengan dunia. Searah dengan itulah, Bloesch melihat bahwa dalam era ini yang diperlukan bukan hanya proklamasi Injil secara verbal, tetapi juga life-style orang percaya. ${ }^{45}$ Perkembangan teknologi informasi dan budaya belanja yang menawarkan berbagai produk yang memanjakan konsumen, perlu menjadi keprihatinan tersendiri bagi anak-anak Allah. Dengan membangun gaya hidup sederhana bahkan kerelaan untuk berbagi ${ }^{46}$ inilah kesejatian mentalitas kerajaan anak-anak Allah.

\footnotetext{
${ }^{42} \mathrm{Bab} 5$ "where to go from 'here': Following Jesus and His Discipleship on the global Road dalam Lausanne Occasional Paper 30," diakses dari www.lausanne.org

${ }^{43}$ Chapter 4 "Christianity in Global Age" dalam LOP 30.

${ }^{44}$ Era informasi dan teknologi sebagai pemandu globalisasi telah memanjakan kehidupan manusia, sehingga budaya tersebut telah mengikis kemampuan membedakan antara keinginan dan kebutuhan, serta melunturkan kemauan untuk bergaya hidup sederhana.

${ }^{45}$ Lih. Donald G. Bloesch, The Christian Witness in a Secular Age: An Evaluation Of Nine Contemporary Theologians (Eugene: Wipf and Stock Publishers, 2002), 135.

${ }^{46}$ Lihat gaya hidup sederhana dalam proposal Sider dalam menanggapi kemiskinan di dunia, agar orang percaya memiliki kemurahan hati dengan membagikan kepemilikannya. Ronald J. Sider, Just Generosity (Grand Rapids: Baker Books, 2002), 222.
} 


\section{Melahirkan dan Mengutus Para Tentmakers}

Dalam mewujudkan fungsi sebagai globalizer yang mampu menyatakan pengaruh atas seluruh aspek kehidupan, The Cape Town Commitment juga menegaskan bahwa orang percaya dapat mengerjakan profesionalismenya sebagai tentmakers yang diintegrasikan dalam strategi misi global, karena setiap aspek dari globalisasi merupakan satu kesempatan bagi orang percaya untuk membagikan dan mendemonstrasikan Injil. ${ }^{47}$ Tantangan besar bagi kekristenan injili adalah bagaimana untuk mengintegrasikan pengaruh injil dan pengaruh karir dalam proses dunia globalisasi. Karena itu Marty Shaw mengusulkan pendekatan misi $360^{\circ}$, yang melihat seluruh aspek kehidupan tidak linear tetapi lebih kepada sebuah lingkaran yang terdiri dari aspek-aspek kehidupan tersebut. Searah dengan hal itu dalam menjawab kebutuhan akan keutuhan di konteks pasca modern ini, maka dibutuhkan juga pemberitaan Injil yang memenuhi kebutuhan tersebut. Inilah yang dinamakan oleh Stanley J. Grenz sebagai Injil postdualistik. ${ }^{48}$ Dalam hal ini, Marty Shaw juga menegaskan bahwa "Globalization is affecting all aspects of societies today. Missions in this reality must seek to intentionally model the Gospel in all areas, not just the religious. The idea of the Gospel going from everywhere to everywhere should not be just a geographical issue, but one that involves all aspects of culture and society, that is a holistic gospel for a

\footnotetext{
${ }^{47}$ Lihat point 3 dalam The Third laussane Congress, hl. 192-3 yang menegaskan point kebenaran dan tempat kerja. Yang mendorong orang percaya, gereja, para pemimpin dan kaum professional untuk berusaha memenuhi panggilan misi Allah dalam hidup keseharian untuk menjadi kesaksian Injil Kristus.

${ }^{48}$ Selain Injil postdualistik, Stanley J. Grenz juga melihat sifat-sifat Injil dalam situasi postmodernisme sebagai: 1) Injil Postindividualistik, yang menentang ciri modernisme dalam meninggikan individu sedangkan postmodernisme berfokus pada komunitas. Sifat ini mendorong untuk melihat pentingnya aspek komunitas iman dalam penginjilan. 2) Injil postrasionalistik, jika modernisme mengagungkan rasio, maka postmodernisme melihat manusia bukan hanya terdiri atas dimensi kognitif. Karena itu dalam situasi demikian Injil harus diberitakan dengan tidak lagi fokus pada proposisi sebagai inti pusat iman Kristen namun harus memperhatikan dimensi intelektual yang dinamis dalam pengalaman manusia dan usaha untuk menjelaskan arti hidup ini. 3) Injil Postnoetisentrik, bahwa sifat ini menekankan relevansi iman dalam setiap dimensi kehidupan. Komitmen pada Kristus bukan hanya sekedar komitmen intelektual atau menyesuaikan pikiran dengan doktrin ortodoks, namun komitmen yang berakar didalam hati. Lih. Stanley J. Grenz, A Primer On Postmodernisme (Yogyakarta: Yayasan Andi, 2001), 271-281.
} 
holistic mission". 49

Pemuridan merupakan salah satu strategi yang mendasar atas setiap orang percaya dalam menghadapi situasi global dan melahirkan para tentmakers yang dapat merembes kedalam seluruh lapisan kehidupan. David F. Wells melihat kembali makna keberadaan murid dalam menghadapi globalisasi sebagai perubahan situasi, dimana dalam melihat pemuridan tersebut Wells menekankan pada kebenaran, otentisitas dan visi global. ${ }^{50}$ Searah dengan itu, Laussanne Occasional Paper juga menyatakan dalam kalimat "back to basics: mission and discipleship". Ini menekankan bahwa warga gereja memiliki tugas untuk membentuk anggota-anggotanya menjadi biblically-grounded cosmopolitans, sehingga dapat menjadi murid-murid yang melihat inkarnasi kekristenan dalam situasi global dan respek dengan situasi masyarakat disekitarnya.

Dalam meningkatnya arus liberalisasi tenaga kerja sebagai komitmen dari MEA, tentunya akan meningkatkan satu keragaman dalam masyarakat ASEAN. Meningkatnya arus gerak kehidupan masyarakat ASEAN, mendorong warga kerajaan Allah untuk bergerak dan bersentuhan langsung dalam meningkatnya kemajemukan. Ini merupakan peluang bagi orang percaya untuk menyebar, mengenal dan menjalin persahabatan dengan masyarakat ASEAN non-Kristen. Dalam meningkatnya kemajemukan ini, patutlah kita juga memperhatikan data yang disampaikan oleh Todd M. Johnson yang diterbitkan oleh Atlas of Global Christianity, 1910-2010. Dimana adanya kecenderungan bahwa kecilnya koneksi orang Kristen dengan Muslim, Hindu dan Budha. Riset tersebut menyatakan bahwa 86\% dari penganut Muslim, Hindu dan Budha secara pribadi tidak mengenal seorang Kristen. Todd melihat bahwa ini adalah suatu kesempatan bagi kekristenan untuk merealisasikan keindahan partikular dan universal dalam sebuah kekristenan global yang sejati, yaitu dengan mempersiapkan untuk pewartaan Injil atas semua orang. ${ }^{51}$

\footnotetext{
${ }^{49}$ Marty Shaw, "The Future Of Kingdom Work In A Globalization World" dalam Globalization and the Gospel: Rethinking Mission in the Contemporary World, Lausanne Occasional Paper No. 30, Pattaya 29 September - 5 Oktober 2004. Dapat di akses di www.lausanne.org.

${ }^{50}$ David F. Wells, Christian Dischipleship in a Postmodern World, 19-33.

${ }^{51}$ Todd M. Johnson, "Globalization, Christian Identity, and Frontier Missions" dalam International Journal of Frontier Missiology, 27:4 (Winter 2010): 165-169.
} 


\section{PENUTUP}

Pemerintahan Allah atas ciptaan yang telah didelegasikan kepada manusia telah mengalami pembaharuan didalam dan melalui karya Yesus Kristus yang memiliki otoritas supra-global, dan Allah menempatkan umat tebusan-Nya kedalam maksud semula sebagai bagian dari pemerintahan tersebut. Pemerintahan yang dikerjakan melalui karya Roh Kudus untuk terus memelihara dan mendorong umat-Nya dalam otoritasnya memancarkan rekonsiliasi dan restorasi dalam setiap aspek kehidupan manusia. Yesus Kristus sebagai klimaks pemerintahan Allah dalam sejarah kehidupan manusia, karena Dia adalah Raja atas segala raja, kini dan yang akan datang, kekal selamanya.

Dengan demikian umat Allah sebagai warga dan bagian dari pemerintahan Allah, telah dibukakan dihadapannya akan situasi global, khususnya MEA. Selayaknyalah umat Allah saat ini, berpikir dan bertindak dalam aspek-aspek kehidupan yang seluas-luasnya dengan memperlihatkan secara nyata peran praktis yang dapat diwujudkan gereja sebagai bagian dari bangsa Indonesia ini dan tentunya bagian dari pemerintahan Allah. MEA (globalisasi) merupakan tantangan untuk mengukur seberapa jauh ragi pemerintahan umat-Nya dalam mengkhamiri seluruh 'adonan' (aspek-aspek) di dunia ini. Permasalahan yang akan muncul sebagai konsekuensi dari MEA, juga pasti akan menekan gereja dan dapat menciptakan masalah baru dalam gereja, karena itu butuh tindakan antisipatif. Dengan demikian sebagai umat yang telah menerima otoritas-Nya atas dunia secara global, umat Allah sebagai komunitas global bertanggung jawab untuk mengejawantahkan peran tersebut dalam menyongsong dan menjalani MEA, sehingga setiap mata menyaksikan teater kemuliaan pemerintahan Allah di tengah dunia, melalui ketaatan dan keterlibatan umat-Nya sebagai globalizer. 


\section{DAFTAR PUSTAKA TERPILIH}

Bloesch, Donald G. The Christian Witness in a Secular Age: An Evaluation Of Nine Contemporary Theologians. Eugene: Wipf and Stock Publishers, 2002.

Media Komunikasi Direktorat Jenderal Kerjasama ASEAN. Majalah Masyarakat ASEAN, Edisi 7 (Maret 2015).

Ott, Craig dan Harold A. Netland (ed). Globalizing Theology: Belief and Practice in an Era of World Christianity. Grand Rapids: Baker Academic, 2006.

Platinga Jr, Cornelius. Engaging God's World: A Christian of Faith, Learning, and Living. Grand Rapids: William B. Eerdmans Publishing Company, 2002.

Prince, Joseph. Destined To Reign: The secret to effortless success, wholeness and victorious living. Oklahoma: Harrison House Publishers, 2011.

Samuel, Vinay. "Evangelical Response to globalization: an Asian Perspective" dalam Transformation 16/1, 1999.

Sider, Ronald J. Just Generosity. Grand Rapids: Baker Books, 2002.

Rice Christians In Age Of Hunger. Dallas, London, Vancouver, Melbourne: Word Publishing, 1990.

Song, Choan-Seng. Yesus dan Pemerintahan Allah. Jakarta: BPK Gunung Mulia, 2010.

The Laussane Movement, Globalization and the Gospel: Rethinking Mission in the Contemporary World, Lausanne Occasional Paper No. 30, dalam www.lausanne.org

The Third Lausanne Congress on World Evangelization: The Cape Town Commitment, 2010, dalam www.lausanne.org

Wells, David F. “Christian Dischipleship in a Postmodern World," JETS 51/1 (March 2008).

Winter, Ralph D. and Steven C (ed). Perspectives: On The World Christian Movement. Pasadena: William Carey Library, 2009. 